A Practical Introduction to Computer Graphics 


\section{Macmillan Computer Science Series}

Consulting Editor

Professor F. H. Sumner, University of Manchester

S. T. Allworth, Introduction to Real-time Software Design

Ian O. Angell, A Practical Introduction to Computer Graphics

G. M. Birtwistle, Discrete Event Modelling on Simula

T. B. Boffey, Graph Theory in Operations Research

Richard Bornat, Understanding and Writing Compilers

J. K. Buckle, The ICL 2900 Series

J. K. Buckle, Software Configuration Management

Robert Cole, Computer Communications

Derek Coleman, $A$ Structured Programming Approach to Data*

Andrew J. T. Colin, Fundamentals of Computer Science

Andrew J. T. Colin, Programming and Problem-solving in Algol 68*

S. M. Deen, Fundamentals of Data Base Systems*

J. B. Gosling, Design of Arithmetic Units for Digital Computers

David Hopkin and Barbara Moss, Automata*

Roger Hutty, Fortran for Students

Roger Hutty, Z80 Assembly Language Programming for Students

H. Kopetz, Software Reliability

Graham Lee, From Hardware to Software: and introduction to computers

A. M. Lister, Fundamentals of Operating Systems, second edition*

G. P. McKeown and V. J. Rayward-Smith, Mathematics for Computing

Brian Meek, Fortran, PL/I and the Algols

Derrick Morris and Roland N. Ibbett, The MU5 Computer System

John Race, Case Studies in Systems Analysis

Peter J. L. Wallis; Portable Programming

I. R. Wilson and A. M. Addyman, A Practical Introduction to Pascal

* The titles marked with an asterisk were prepared during the Consulting Editorship of Professor J. S. Rohl, University of Western Australia. 


\title{
A Practical Introduction to Computer Graphics
}

\author{
Ian O. Angell
}

Department of Statistics and Computer Science, Royal Holloway College,

University of London 
(C) Ian O. Angell 1981

All rights reserved. No reproduction, copy or transmission of this publication may be made without written permission.

No paragraph of this publication may be reproduced, copied or transmitted save with written permission or in accordance with the provisions of the Copyright Act 1956 (as amended).

Any person who does any unauthorised act in relation to this publication may be liable to criminal prosecution and civil claims for damages.

First published 1981 ,

Reprinted 1982 (twice), 1983 (three times), 1984, 1985

Published by

Higher and Further Education Division

MACMILLAN PUBLISHERS LTD

Houndmills, Basingstoke, Hampshire RG21 2XS

and London

Companies and representatives

throughout the world

ISBN 978-0-333-31083-0

ISBN 978-1-349-16592-6 (eBook)

DOI 10.1007/978-1-349-16592-6 


\section{Contents}

Preface vii

1. An Informal Introduction to Two-dimensional Graphics 1

2. An Introduction to Two-dimensional Geometry 11

3. Transformations of Two-dimensional Space; Matrix Representation 23

4. Clipping and Covering $\quad 32$

5. The Coordinate Geometry of Three-dimensional Space 42

6. Matrix Transformation of Three-dimensional Space; Orthographic Projections

$\begin{array}{ll}\text { 7. Perspective and Stereoscopic Views } & 74\end{array}$

8. Hidden Line Algorithms $\quad 84$

$\begin{array}{ll}\text { 9. Setup Techniques } & 97\end{array}$

$\begin{array}{lr}\text { 10. Computer Movies } & 111\end{array}$

$\begin{array}{ll}\text { 11. Projects } & 127\end{array}$

$\begin{array}{ll}\text { 12. Conclusion: What Next? } & 138\end{array}$

$\begin{array}{ll}\text { Index } & 143\end{array}$ 


\section{Preface}

Until recently, all but the most trivial computer graphics was the province of specialised research groups. Now with the introduction of reasonably priced graphics devices, the subject will reach many more users and its full potential can be realised. Computer-produced pictures always impress the layman, and the 'mysterious' techniques used for drawing them have gained a (false) reputation for complexity.

This book, as its title implies, is a practical first step in understanding the methods of computer graphics. After studying the contents and implementing the examples and exercises, the reader will be ready to attempt most tasks in graphics, whether these be the production of elementary data graphs, pie charts, etc., the drawing of patterns or diagrams for books, pamphlets or as teaching aids (all the diagrams in this book were drawn by computer) or the development of far more sophisticated design and technical drawing programs used in the aeronautics, automobile and other industries. Hints on how to tackle some of these sophisticated programs are also given.

It is assumed that the reader has an elementary knowledge of the Fortran IV programming language, and of cartesian coordinate geometry. This knowledge will be used to produce simple diagrams, and to produce the basic programming tools and routines required for the more 'complicated' designs. Then, hopefully, the reader will be inspired to seek a greater understanding of geometry and also to read more advanced works on computer graphics and to use the commercially available packages.

This book was designed to be completely self-contained, therefore no references are given. The contents reflect what I consider to be the logical development of the basic concepts in computer graphics, produced independently of the preconceived ideas of other authors, although standard terminology is used where appropriate.

The only way to understand any branch of computer science completeiy is to study and write a large number of programs; this is why the format of this book is that of 'understanding through worked examples'. The chapters are centred around numerous examples and the ideas that lead from them. Many students readily understand the theory behind graphics, but they have great difficulty in implementing the ideas. Hence great emphasis is placed on the program listings; over seventy program segments are given - some quite substantial. Total understanding will only be achieved by running these programs and experimenting 
with them. The programs can be thought of as an embryonic graphics package, but most importantly they are the means of describing the algorithms required in the solution of the given problems. They are readily translatable into other computer graphics languages such as Pascal or Basic. The routines described were devised for use with both Tektronix Interactive Graphics Consoles and microfilm, but again they can be made to run on any graphics system, be they paper plotters, other 'scopes, etc., with a minimum of thought.

The figures drawn are deliberately kept simple in order that the description of the detail in scenes should not obscure the new ideas being introduced.

Complexity is left to the reader! No claims are made regarding the efficiency of the program segments; instead, a balance is maintained between efficiency of code and clarity of the description of the algorithm. As far as possible the programs were written in modular form. There are many cases where, by reorganising the programs, combining routines and perhaps obscuring the code, redundancy of data variables and statements may be eliminated. This can be considered a general exercise that runs throughout the book.

The main purpose of this book, which is essentially a third-year degree course given to undergraduates at Royal Holloway College, University of London, is to set out the groundwork of computer graphics, but to leave as much as possible to the imagination of the user - an exciting prospect. As one who found it 'difficult to draw a straight line with a ruler', I hope that my excitement in the discovery of computer graphics and its potential will become apparent in the following pages. I have been most gratified by the high standard and ingenuity of design produced by my students. In fact I have used diagrams produced by four of them: Hilary Green (figure 4.1), Jemma Coombe (figure 11.1), Helen Davies (figure 11.8) and Paul McLean-Thorne (figure 11.10). They have found that computer graphics is fun; I hope the reader will make the same discovery and spend many enjoyable and productive hours in front of a graphics console.

For those wishing to study computer graphics in more detail after reading this book, I recommend that they read W. M. Newman and R. F. Sproull, Principles of Interactive Computer Graphics (McGraw-Hill, 1973). It gives a good survey of the more complicated and theoretical aspects of the subject as well as containing an excellent bibliography. 


\section{Acknowledgements}

I wish to thank Professor H. J. Godwin for his help and encouragement and John Anderson for his valuable assistance with my computer graphics course. The photographic reproduction of all the diagrams and program listings in this book would not have been possible without the untiring work of J. G. Davies, to whom I am very grateful. Finally I would like to express my gratitude to my wife Florence for her cheerful support during the writing of this book. 